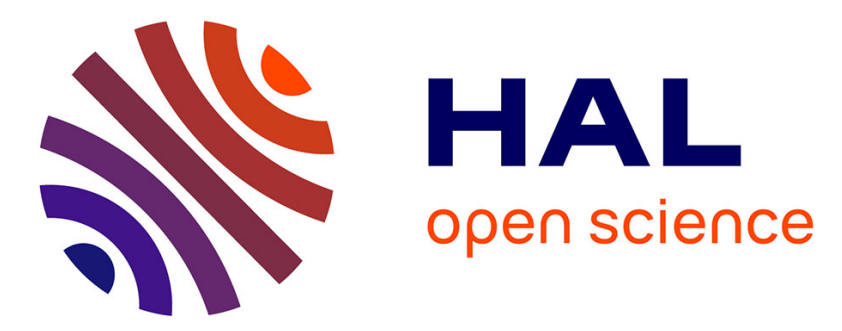

\title{
Interleukin-1 system in the human fallopian tube - no spatial but a temporal regulation of mRNA and protein expression
}

\author{
A.P. Hess, D.M. Baston-Buest, A. Schanz, J. Hirchenhain, P. Bielfeld, J.S. \\ Kruessel
}

\section{To cite this version:}

A.P. Hess, D.M. Baston-Buest, A. Schanz, J. Hirchenhain, P. Bielfeld, et al.. Interleukin-1 system in the human fallopian tube - no spatial but a temporal regulation of mRNA and protein expression. Molecular and Cellular Endocrinology, 2009, 303 (1-2), pp.7. 10.1016/j.mce.2009.01.017 . hal00499112

\section{HAL Id: hal-00499112 \\ https://hal.science/hal-00499112}

Submitted on 9 Jul 2010

HAL is a multi-disciplinary open access archive for the deposit and dissemination of scientific research documents, whether they are published or not. The documents may come from teaching and research institutions in France or abroad, or from public or private research centers.
L'archive ouverte pluridisciplinaire HAL, est destinée au dépôt et à la diffusion de documents scientifiques de niveau recherche, publiés ou non, émanant des établissements d'enseignement et de recherche français ou étrangers, des laboratoires publics ou privés. 


\section{Accepted Manuscript}

Title: Interleukin-1 system in the human fallopian tube - no spatial but a temporal regulation of $\mathrm{mRNA}$ and protein expression

Authors: A.P. Hess, D.M. Baston-Buest, A. Schanz, J. Hirchenhain, P. Bielfeld, J.S. Kruessel

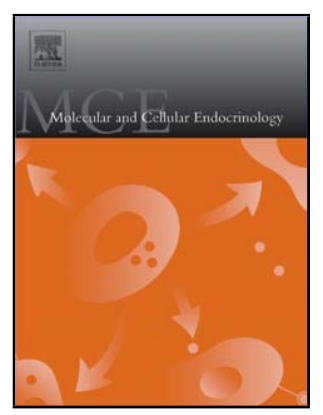

PII: S0303-7207(09)00060-4

DOI: doi:10.1016/j.mce.2009.01.017

Reference: MCE 7127

To appear in: Molecular and Cellular Endocrinology

Received date: 3-9-2007

Revised date: $15-1-2009$

Accepted date: 18-1-2009

Please cite this article as: Hess, A.P., Baston-Buest, D.M., Schanz, A., Hirchenhain, J., Bielfeld, P., Kruessel, J.S., Interleukin-1 system in the human fallopian tube - no spatial but a temporal regulation of mRNA and protein expression, Molecular and Cellular Endocrinology (2008), doi:10.1016/j.mce.2009.01.017

This is a PDF file of an unedited manuscript that has been accepted for publication. As a service to our customers we are providing this early version of the manuscript. The manuscript will undergo copyediting, typesetting, and review of the resulting proof before it is published in its final form. Please note that during the production process errors may be discovered which could affect the content, and all legal disclaimers that apply to the journal pertain. 
Running title: Interleukin-1 system in human fallopian tube

\title{
5 Interleukin-1 system in the human fallopian tube - no spatial but
}

\section{a temporal regulation of $\mathrm{mRNA}$ and protein expression}

\author{
A.P. Hess ${ }^{\mathrm{a}^{*}}$, D.M. Baston-Buest ${ }^{\mathrm{a}}$, A. Schanz ${ }^{\mathrm{a}}$, J. Hirchenhain $^{\mathrm{a}}$, \\ P. Bielfeld ${ }^{\mathrm{b}}$, J.S. Kruessel ${ }^{\mathrm{a}}$
}

10

${ }^{\mathrm{a}}$ Department of Gynecology and Obstetrics, Heinrich-Heine-University Medical Center, 40225 Duesseldorf, Germany

bovum, Center for Reproductive Medicine, Akazienallee 8-12, 45127 Essen, Germany

*Correspondence to: Department of Gynecology and Obstetrics, Heinrich-HeineUniversity Medical Center, 40225 Duesseldorf, Germany. Tel.: +49 2118104060, fax: $+492118116787$. 


\begin{abstract}
The human fallopian tube provides the environment for the first 5 days of embryonic development in vivo. The IL-1 system is involved in human embryo implantation.

25 This study aimed to investigate IL-1 $\beta$, IL-1ra and IL-1R tI expression within the length of the human fallopian tube on mRNA- and protein-level in samples from proliferative versus secretory phase, postmenopause samples (PMP) and samples from intra- (IUP) and extrauterine (EUP) pregnancies to examine possible spatial and hormonal induced changes (fimbrial, ampullary and isthmic tube segments). On

30 mRNA-level, IL-1 $\beta$ was expressed in all samples except in PMP. IL-1R tI could be detected in all samples whereas IL-1 ra was only expressed in secretory phase and the IUP sample. Immunohistochemically we could detect IL-1 $\beta$ and IL-1R t1 protein in all proliferative and secretory phase samples with maximum intensity in secretory phase samples whereas IL-1ra was expressed in secretory phase samples only.

35 Overall no spatial but temporal differences possibly due to hormonal changes could be observed suggesting a precise regulation of the IL-1 system, especially for IL-1ra and moreover a stable molecular architecture within the full length of the fallopian tube.
\end{abstract}


40 Keywords: Interleukin-1 (IL-1) system, human fallopian tube, Interleukin-1 receptor type I (IL-1R tI), Interleukin-1 receptor antagonist (IL-1ra), implantation, spatial and temporal expression pattern 


\section{Introduction}

The factors involved in the complex embryonic maturation and in the embryomaternal dialogue resulting in eutopic embryonic implantation are poorly understood. The human fallopian tube is the place of fertilization and also provides the natural environment for the first five days of embryonic development (Hess et al., 2007b). It is, as well, the most common place for ectopic implantation. The preimplantation embryo produces several factors during its development to signal its presence to the maternal organism. Appropriate interaction between the preimplantation embryo and the maternal system is at least partly controlled by paracrine cytokines (Hess et al., 2007a; Popovici et al., 2006). Knowledge of expression patterns of these cytokines could possibly help to gain a better insight of the physiological course of

55 implantation. Although multiple studies have examined the existence and influence of various cytokines at the embryonic-maternal interface (Hess et al. 2007a; Popovici et al., 2006), as yet, little is known about cytokine production by the human fallopian tube (Brabec and Hill, 2000).

The Interleukin-1-system is composed of two agonists, Interleukin-1 $\alpha$ (IL-1 $\alpha)$

60 and Interleukin-1 $\beta$ (IL-1 $\beta$ ), one antagonist, the Interleukin-1 receptor antagonist (IL1ra) and two membrane-bound receptors, Interleukin-1 receptor type I (IL-1R tI) and II (IL-1R tII) (Dinarello et al., 1994; Dimitriadis et al., 2005). All components of the IL-1 family in humans are located on chromosome 2 and the DNA-, RNA- and protein-structures are all well characterized for many species. Both agonists are

65 initially synthesized as precursor proteins of $31 \mathrm{kDa}$. The mature proteins have a molecular weight of $17 \mathrm{kDa}$ and although the amino acid sequences have a similarity 
of only $\sim 22 \%$, they induce the same biological responses (Dower et al., 1986). There is also a high similarity between the cDNA-sequences of IL- $1 \alpha$ and $-\beta$ in mice and human (March et al., 1985). Interleukin-1 receptors type I and II both possess a transmembraneous domain and their extracellular portions are homologous with similar binding affinities for the agonists and antagonist. There is also a soluble form of the IL-1R tII. The IL-1 receptor type I wich is found in low numbers on almost all cell surfaces whereas IL-1R tII is found primarily on white blood cells. Only the binding of either IL- $1 \alpha$ or $-\beta$ to the IL-1 receptor type I results in signal transduction 75 (Sims et al., 1993) with receptor type II and the soluble IL-1 receptor acting as competitors of the receptor type I (Colotta et al., 1993). The IL-1 receptor antagonist binds with a high affinity to both receptors and prevents signal transduction by IL-1 $\alpha$ and $-\beta$ (Hannum et al., 1990).

The IL-1 system is intimately involved in embryonic implantation. In humans, the IL-

80 1R tI has been detected in total human endometrium (Simon et al., 1993b) and, more specifically, in endometrial epithelial cells with a maximum mRNA- and protein expression during the luteal phase (Simon et al., 1993a) - the time of embryonic attachment and implantation. IL-1 $\beta$-mRNA was detected in secretory human endometrium beginning on day 23 of the menstrual cycle (Kauma et al., 1990). In the 85 last years, all major components of the IL-1-system, namely IL-1 $\beta$, IL-1ra and IL-1R tI were detected immunohistochemically in single preimplantation embryos (De Los Santos et al., 1996). In vitro fertilized, cultured human embryos have been shown to produce both IL- $1 \alpha$ and IL-1 $\beta$. High concentrations $[>60 \mathrm{pg} / \mathrm{ml}$ and $>80 \mathrm{pg} / \mathrm{ml}]$ of these cytokines in culture media have been correlated with successful implantation 
90 after intrauterine transfer of these embryos (Sheth et al., 1991), although other authors could not detect IL-1 $\alpha$ or $-\beta$ in culture fluids of human embryos (Seifer et al., 1993). In mice, IL-1 $\alpha$ and IL-1 $\beta$ have been detected and localized at mRNA- and proteinlevel in endometrial endothelial cells (Tackacs et al., 1988) in increasing levels from day 3 of pregnancy peaking between days 4 and 5 (De et al., 1993). Blastocyst

95 implantation is known to occur late on day 4. It was shown that systemically administered recombinant human IL-1ra given intraperitoneally from day 3 to day 6 of pregnancy inhibited embryonic implantation in mice (Simon et al., 1994a). It was also demonstrated that in vitro cultured single mouse embryos at various stages of preimplantation development express different patterns of mRNA for IL-1 $\beta$, IL-1ra and IL-1R tI (Simon et al., 1994b).

In summary, there is an increasing body of evidence that the IL-1 system is involved in early embryonic development and implantation. The aim of our study was to detect a potentially spatial and temporal IL-1 $\beta$-, IL-1ra- and IL-1R tI-expression pattern on mRNA- and protein-level in human fallopian tubes and to describe possible hormonally regulated changes since these changes might influence the time and place of embryonic implantation. 


\section{Material and Methods}

\subsection{Patients}

Patients who underwent hysterectomy or tubal surgery for reasons other than cancer (except one patient with intrauterine pregnancy diagnosed of cervical cancer) were asked to participate in this study. Each participating patient signed an informed consent that was prior approved by the human investigations committee of the Heinrich-Heine University medical school. Menstrual phase was determined by the

115 patient's history and dating was verified by histological examination of the endometrium according to Noyes et al. (1950) and serum-levels of estradiol, progesterone, LH and FSH were measured. The indications for surgery were as follows: hysterectomy for benign reasons: 19 patients; ectopic tubal pregnancies: 3 patients and one patient received a radical hysterectomy in the $9^{\text {th }}$ week of gestation 120 due to cervical cancer. The mean age of the patients was $39 \pm 7.9 \mathrm{yr}$, range $26-51 \mathrm{yr}$. Tissue samples from the fimbrial, ampullary and isthmic parts of the fallopian tubes were collected from both sides. Tissue samples were than split in half: one half was fixed in $4 \%$ paraformaldehyde and later processed for immunohistochemistry, the other half was snap-frozen in liquid nitrogen and stored at $-80{ }^{\circ} \mathrm{C}$ until RNAextraction.

\subsection{RNA isolation}

The isolation of RNA from the tissue samples was done as described previously (Chomczynski and Sacchi, 1987) with the RNA-STAT-60 reagent (Tel-

130 Test "B" Inc., Friedenswood, TX, USA). Briefly, tissue samples were washed three 
times in phosphate buffered saline (PBS, GibCo BRL, Grand Island, NY, USA) to remove blood contamination. $100 \mathrm{mg}$ tissue was homogenized in $1 \mathrm{ml}$ of RNASTAT-60 reagent. Total RNA was separated from DNA and proteins by adding chloroform and precipitated using isopropanol. Precipitate was washed two times in

$13575 \%$ ethanol, air dried and resuspended in diethylpyrocarbonate- (DEPC) treated $\mathrm{dH}_{2} \mathrm{O}$. The amount and purity of the isolated RNA was quantitated by spectrophotometry in a GenQuant RNA/DNA calculator (Pharmacia Biotech Ltd., Cambridge, UK).

Sequences of cDNA-clones for the mRNAs that should be detected in human fallopian tubes ( $\beta$-actin, IL-1 $\beta$, IL-1ra and IL-1R tI) were obtained from the GenBank Database of the National Center for Biotechnology Information (NCBI) of the National Institutes of Health (NIH, Internet address:

145 http://www.ncbi.nlm.nih.gov/sites/entrez). One set of primer-sequences was found with the help of the program OLIGO 4.1 Primer Analysis Software (National Bioscience, Plymouth, MN, USA) and synthesized by MWG Biotech (MWG Biotech AG, Ebersberg, Germany). To ensure that the product detected resulted from amplification of cDNA rather than contaminating genomic DNA, primers were 150 designed to cross intron/exon boundaries. The human $\beta$-actin primers that were used to amplify an internal standard were obtained from Clontech Laboratories Inc., Palo Alto, CA, USA. The primer-sequences, locations on the cDNA and the sizes of the amplified fragments are listed in Table 1. 
For each mRNA to be detected, $20 \mu 1$ RT-MasterMix were prepared ( $5 \mathrm{mM}$ $\mathrm{MgCl}_{2}, 1 \times \mathrm{RT}$ Buffer, $1 \mathrm{mM}$ dNTPs (each), $2.5 \mu \mathrm{M}$ Oligo d(T) ${ }_{16}, 1 \mathrm{U} / \mu 1 \mathrm{RNase}$

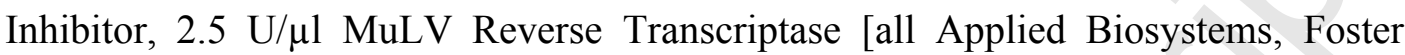
City, CA, USA], and $1 \mu \mathrm{g}$ total RNA, DEPC-treated $\mathrm{H}_{2} \mathrm{O}$ ad $20 \mu \mathrm{l}$ ) and filled into a MasterMix in PCR-tubes was covered with $50 \mu \mathrm{l}$ of light white mineral oil (Sigma, St. Louis, MO, USA) and kept on ice until the RT.

The RT-reaction was carried out in the DNA Thermal Cycler 480 by using a program with the following parameters: $42{ }^{\circ} \mathrm{C}, 15 \mathrm{~min} ; 99{ }^{\circ} \mathrm{C}, 5 \mathrm{~min} ; 4{ }^{\circ} \mathrm{C}, \infty$. After the 165 reaction was complete, samples were stored at $-20{ }^{\circ} \mathrm{C}$ until the PCR.

\subsection{Polymerase Chain Reaction (PCR)}

$2.5 \mu 1$ RT-products were mixed with $77.5 \mu$ PCR-Mastermix containing 1.25 $\mathrm{mM} \mathrm{MgCl} 2,1 \times$ PCR-Buffer, $0.125 \mu \mathrm{M}$ 3' and 5' primer-mix for either IL-1 $\beta$, IL-1 ra,

170 IL-1R tI or $\beta$-actin, $1 \mathrm{mM}$ dNTPs (each), $1.5 \mathrm{U} / \mu 1$ AmpliTaq ${ }^{\circledR}$ DNA Polymerase, DEPC-treated $\mathrm{dH}_{2} \mathrm{O}$ ad $80 \mu \mathrm{l}$ (Applied Biosystems) and the reaction-mix was covered with $50 \mu$ light white mineral oil, put in the DNA Thermal Cycler 480 and heated to $95^{\circ} \mathrm{C}$ for $5 \mathrm{~min}$ to activate the enzyme. After completion of 30 cycles of 94 ${ }^{\circ} \mathrm{C}$ for $45 \mathrm{sec}, 54{ }^{\circ} \mathrm{C}$ for $45 \mathrm{sec}$ and $72{ }^{\circ} \mathrm{C}$ for $60 \mathrm{sec}$, the reaction was terminated at 72

$175{ }^{\circ} \mathrm{C}$ for $7 \mathrm{~min}$ and cooled down to $4{ }^{\circ} \mathrm{C}$. PCR-products were stored at $-20{ }^{\circ} \mathrm{C}$ until $2 \%$ agarose-gel electrophoresis was carried out in the presence of ethidiumbromide. After 
completion of electrophoresis, the agarose-gel was analyzed on the GelDoc 1000 system (Bio-Rad Laboratories, Hercules, CA, USA). DNA-size calculation was carried out by using the Molecular Analyst Software (Bio-Rad Laboratories).

180

\subsection{Immunohistochemical staining procedure}

The immunostaining procedure was performed on fallopian tubes sections by the avidin-biotin-peroxidase $(A B C)$ method. Serial sections from each sample were mounted on slides, fixed in formalin and embedded in paraffin. The first section was processed for hematoxylin-eosin staining.

Sections were deparaffinized in xylene, rehydrated through graded alcohols, and washed in phosphate-buffered saline (PBS; Sigma). Endogenous peroxidases were blocked with $1 \% \mathrm{H}_{2} \mathrm{O}_{2}$ in $96 \%$ methanol, and non-specific binding was blocked with non-fat milk $5 \%$ in PBS at room temperature. After washing with $0.05 \%$ Tween ${ }^{\circledR} 20$

190 in PBS (PBS-T; Sigma), the slides were incubated at room temperature for 30min with the primary antibodies: monoclonal mouse anti-human IL-1 $\beta$ antibody, monoclonal mouse anti-human IL-1R tI antibody, and polyclonal rabbit anti-human IL-1ra (all from Genzyme Corp., Cambridge, MA, USA) at $20 \mu \mathrm{g} / \mathrm{ml}, 50 \mu \mathrm{g} / \mathrm{ml}$, and $20 \mu \mathrm{g} / \mathrm{ml}$ respectively. Control incubations included deletion of the primary antibody.

195 After rinsing with PBS-T, sections were incubated with a secondary antibody at room-temperature for 30min: anti-rabbit IgG (whole molecule) biotin conjugate (200 $\mu \mathrm{g} / \mathrm{mL}$; Sigma) and anti-mouse IgG biotin conjugate (Vector Laboratories INC, Burlingame, CA, USA) at $150 \mu \mathrm{g} / \mathrm{ml}$. Histological sections were incubated with Vectastain ABC Kit (Vector Laboratories) reagents for $60 \mathrm{~min}$ at room temperature. 
200 Immunoreaction products were visualized by incubating sections with the substrate solution in $0.1 \mathrm{M}$ Tris- $\mathrm{HCl} \mathrm{pH} 8.2$ buffer blocking alkaline phosphatase activity with levamisole. Slides were counterstained with $25 \%$ of hematoxylin, then cleared, cover slips applied and finally examined by light microscopy. Positive staining by the primary antibody was indicated by a pink precipitate. The relative intensity of the immunostaining was evaluated by two of the authors in a double-blind manner as absent $(0)$, weakly positive $(+)$, moderate $(++)$ or intense $(+++)$ for biopsy specimens from each portion and each phase of the menstrual cycle. 
3.1 RT-PCR of spatial expression pattern throughout the menstrual cycle

All 19 collected oviduct samples from the proliferative $(n=8)$ and secretory $(n=9)$ phase of the cycle and postmenopausal $(n=2)$ women were divided into fimbrial, ampullary and isthmic parts and investigated separately by RT-PCR. From 215 the total of 19 samples all were positive for $\beta$-actin mRNA expression and therefore considered for further investigation. The following investigation of IL-1 $\beta$, Il-1ra and Il-1R tI expression showed that the presence or absence of the respective gene was constant regarding the spatial distribution. This shows that the gene expression of IL$1 \beta$, Il-1ra and Il-1R tI within the length of the fallopian tube has no spatial difference 220 (Fig. 1).

\subsection{RT-PCR of temporal expression pattern throughout the menstrual cycle}

All 23 collected oviduct samples from the proliferative $(n=8)$ and secretory $(n=9)$ phase of the cycle and from postmenopausal $(n=2)$ women and extra- $(n=3)$ and intrauterine $(\mathrm{n}=1)$ pregnancies were separately investigated by RT-PCR for temporal expression patterns of IL-1 $\beta$, IL-1ra and IL-1R tI. From the total of 23 samples, all were positive for $\beta$-actin mRNA expression and therefore considered for further investigation. The following investigation of IL-1 $\beta$, Il-1ra and Il-1R tI expression showed that there was a temporal and therefore most likely hormonal regulation of two of the target mRNAs. IL-1R tI was expressed in all samples regardless the hormonal situation. IL-1ra mRNA could be detected in samples of the secretory phase and in intrauterine pregnancy, whereas IL-1 $\beta$ could be detected in proliferative and 
secretory phase fallopian tubes and in samples of intra- and extra-uterine pregnancy. This shows that the gene expression of IL-1 $\beta$, Il-1ra and Il-1R tI is temporally regulated within the human cycle (Fig. 1 and 2). Additionally IL-1 $\beta$ is expressed not only in all different hormonal situations investigated but also in oviducts from intraand extrauterine pregnancies.

\subsection{Immunohistochemistry}

The protein expression of IL-1 $\beta$, Il-1ra and Il-1R tI of proliferative phase versus secretory phase samples was evaluated using immunohistochemistry. Figure 3 A-H shows representative samples from fallopian tubes of the secretory phase whereas Fig. 3 I-P shows representative samples from proliferative phase fallopian tubes. Panel A-G and I-O are magnified 200×, panel B-H and J-P 400×. Panels A and

245 B represent the control of secretory phase oviducts, panel I and J represent the negative control (omission of first antibody) of proliferative phase oviducts. We could show a strong expression of IL-1 $\beta$ foremost in the luminal epithelium and also in the small vessels endothelium of secretory phase oviducts (Fig. $3 \mathrm{C}, \mathrm{D}$ ), whereas the staining for IL-1 $\beta$ in the luminal epithelium of proliferative phase oviducts was less intense and only a weak staining was localized in the small vessels endothelium (Fig. $3 \mathrm{~K}, \mathrm{~L}$ ). The IL-1R tI was shown to be expressed in the luminal epithelium, small vessels endothelium and glandular epithelium of secretory phase samples (Fig. 3 E, F). In comparison the proliferative sample showed only a sporadic staining for the IL$1 \mathrm{R}$ tI in the luminal epithelium and no staining either in the vessel endothelium or in 255 the glandular epithelium (Fig.3 M, N). Fig. $3 \mathrm{G}$ and $\mathrm{H}$ show an intense staining of IL- 
1ra in the luminal epithelium and the small vessel endothelium of secretory phase oviducts whereas a staining for IL-1ra in proliferative oviducts was completely absent revealing a strict temporal expression of IL-1 ra.

No staining was observed in the absence of either primary or secondary antibodies. These protein data support the previous mRNA data showing an expression of Il- $1 \beta$ in fallopian tubes of both cycle phases with an increase in the secretory phase as well as a pronounced expression of IL-1R tI in secretory phase oviducts. However, IL-1 ra expression was seen in secretory phase samples only. 


\section{Discussion}

Factors of the embryo-maternal communication that have an influence on maturation and transport of an embryo as it transverses the oviducts are crucial for a successful implantation (Hess et al., 2007a). The fallopian tube on the maternal side plays an important role in providing the place for fertilization as well as an active component for transport and early development of the embryo. Within the oviduct, remarkable changes occur in dependence to the sex steroids estradiol in the proliferative phase and progesterone in the post-ovulatory secretory phase indicating a hormonal cyclicity of the oviduct comparable to the endometrium (Gardner et al., 1996). A growing body of evidence suggests that chemokines of the IL-1 family play

275 an important role at the feto-maternal interface (Krussel et al., 2003). Therefore, the knowledge of normal expression patterns of the IL-1 family members could help in understanding the physiological processes leading to proper maturation and transport of the blastocyst within the fallopian tube and subsequently to a successful intrauterine implantation. Since we have shown before that the human embryo

280 produces IL-1 $\beta$ when cultured in vitro (Krussel et al., 1998), it is reasonable that it also produces IL-1 $\beta$ during its passage through the fallopian tube. Consequently, it is very likely that the fallopian tube as the early communication partner for the developing embryo itself expresses components of the IL-1 family. Therefore, our objective was to first investigate the spatial expression pattern of IL-1 $\beta$, Il-1ra and Il-

$2851 \mathrm{R}$ tI in the human fallopian tube and second to elucidate a possible hormonal influence. Furthermore we wanted to explore whether we could find a hint for an 
abnormal expression pattern or an imbalance of gene expression contributing to a risk of an extrauterine tubal pregnancy.

All collected oviduct samples from the proliferative and secretory phase of the cycle

290 as well as the postmenopausal samples were divided into fimbrial, ampullary and isthmic parts before investigation and prepared separately. This led us to the observation that regardless of the original spatial belonging of the oviduct part, the mRNA expression of IL-1 $\beta$, Il-1ra and Il-1R tI showed no differences at all. These findings on the mRNA level were also proven on the protein level by

295 immunohistochemistry (data not shown). The data support the notion that although the oviduct is compromised of a changing architecture within its full length, the molecular base of gene expression remains the same in all parts of the fallopian tube. Therefore, possible differences in gene expression regarding to the biopsy technique are erased which makes studies involving different parts of the oviduct comparable.

300 Furthermore, our aim was to elucidate whether the sex steroids estrogen and progesterone have an influence on the temporal expression of IL-1 $\beta$, Il-1ra and Il-1R tI during the reproductive phase. Therefore, fallopian tubes from the proliferative and secretory phase of the menstrual cycle as well as oviducts from postmenopausal women were investigated. This showed that IL-1 $\beta$ was only present in samples from

305 the proliferative and secretory phase but in none of the postmenopausal oviducts suggesting a regulation by sex steroids and a role in the process of human reproduction. These data highlight that the oviduct and the uterus underlie partially common most likely hormonally driven regulatory expression phenotypes since a study has shown that IL-1 $\beta$ is expressed as well by epithelial and stromal 
310 endometrium cells throughout the cycle (Simon et al., 1993a). In unison with our immunohistochemistry results they detected an increase of IL-1 $\beta$ immunostaining from proliferative to secretory endometrium suggesting an additional role in supporting the implantation within the endometrium during the window of implantation. On the contrary, another study primarily focused on the expression of

315 Il-1 $\alpha$ by endometrial stromal cells reports a hormonally controlled expression of IL$1 \alpha$ but not for IL-1 $\beta$ or Il-1ra (Pretto et al., 2008). Furthermore, it was shown that incubation of endometrial stromal cells with IL-1 $\beta$ upregulates the expression of IL$1 \beta$ and IL-1ra (Huang et al., 2001) suggesting that besides a hormonal regulation chemokines seem to influence the expression of Il-1 family members in endometrial 320 stromal cells which could be likewise for the tube. In addition an immunohistochemical approach revealed IL-1 $\beta$ staining in the villous cytotrophoblast, syncytiotrophoblast and maternal decidual cells, suggesting an autocrine/paracrine role during the human implantation (Simon et al., 1994b). In contrast to the ligand, we detected mRNA expression of its receptor IL-1R tI in all 325 samples investigated. The immunostaining showed a less intense staining in proliferative phase samples compared to secretory phase oviducts suggesting at least a moderate influence of the sex hormones. Furthermore it provides new evidence that the preimplantation embryo is able to communicate with the maternal side already during its transit through the fallopian tube by its own IL-1 $\beta$ secretion in consent to a 330 study by Strakova et al. (2005) simulating endometrial changes of an early pregnancy in baboons by in vivo infusion of hCG and IL-1 $\beta$. 
In contrast, IL-1 ra mRNA was only detected in progesterone dominated secretory phase samples and in the intrauterine pregnancy sample suggesting a hormonal influenced regulation and further a possible protection mechanism to avoid a false 335 implantation of the embryo within the fallopian tube. The IL-1ra expression seems to be a rather systemic effect independent of the embryos presence since it was equally expressed in both sides of the fallopian tubes of each patient in the secretory phase. IL-1ra's possible protective effect becomes even more likely in the context that IL1ra was not only present in all secretory phase samples and the one investigated

340 sample with an intrauterine pregnancy but did not occur in anyone of the 3 tested fallopian tubes with an extrauterine pregnancy. This hypothesis is furthermore supported by findings of other groups describing a decrease in IL-1ra expression in the human endometrium at the time of implantation to possibly facilitate the embryos invasion into the maternal endometrium (Simon et al., 1995). Another study showed 345 increased levels of IL-1ra in endometrial stromal cells of the secretory phase (Fukuda et al., 1995). Those differences though might be explained by the fact that the first study investigated the mRNA and protein expression for secreted IL-1ra and intracellular IL-1ra whereas the second study did not differentiate between those two forms. The findings of the first study positively correlate with a study in mice where 350 systemically administered IL-1ra prevented embryonic implantation (Simon, 1994a). However, this distinct inhibition of implantation might have been a mouse strain specific effect as a study by Abbondanzo et al. (1996) disproved the latter finding in IL-1R tI female knockout mice showing no deficiency in fertility besides a slightly smaller litter size as well as Cohen and Pollard could not show noticeable fertility 
355 abnormalities in male IL-1R tI knockout mice (1998). On the other hand a recent knock out study with male $\mathrm{IL-1ra-/-}$ mice showed a reduced capacity to fertilize oozytes of wild type females in vitro and a reduced litter size when mated with wild type females (Genaiem et al., 2009). The discrepancy of those studies might have been evolved due to the fact that Abbondanzo et al. e.g. have used an outbread strain with a

360 mutated gene which are known to possibly have an influenced phenotype. Otherwise it might be conceivable that subsequent events in the signaling cascade after blocking a receptor with the receptor antagonist compared to a knock out of the receptor itself may vary and possibly lead to inconsistent results as shown above when data of IL1R tI knock out studies are compared with IL-1ra knock out studies. With regards to

365 the event of extrauterine tubal pregnancy in human it could be possible that not only the absence of IL-1ra but furthermore an inappropriate ratio of IL-1 $\beta$ and IL-1ra favoring IL-1 $\beta$ may serve as one underlying molecular mechanism.

So far most investigations regarding the molecular base of extrauterine pregnancies were conducted in the mouse or baboon model. Therefore little is known in the

370 human system. Huang et al. (2005) investigated fallopian tubes from extrauterine pregnancies versus normal healthy control tubes from tubal ligations. The PCR approach showed partially varying results from our data with an upregulation of IL1R tI and IL-1ra mRNA simultaneous to an IL-1 $\beta$ downregulation in tubes with ectopic pregnancies. The study by Huang et al. applied a quantitative PCR approach 375 using a competitor compared to the qualitative method which was used in this study showing no upregulation of IL-1RtI and a downregulation of IL-1 $\beta$ but rather the presence of both in fallopian tubes of extrauterine pregnancies. Presumptions about a 
regulation can not be drawn therefore. However the upregulation of IL-1 ra in extrauterine tubes is opposed to the absence of IL-1ra in extrauterine and healthy 380 proliferative phase tubes as occurred in the present study. Both studies have investigated a relatively small number of fallopian tube samples most likely due to low availability which might explain the partly varying results.

Based on those findings in human as well as in the animal studies the IL- $1 \beta$ system appears to be involved in the establishment of pregnancy although the exact magnitude is still questionable due to the conflicting data in the literature. Furthermore, rigorous species specific differences might attribute to an inconsistency in the importance of the IL-1 system in implantation as well.

To our knowledge this is the first study to report that the gene expression profile is not altered within the different anatomical parts of the fallopian tube showing a 390 constant gene expression pattern of all IL-1 $\beta$ system factors throughout the complete length of the oviduct investigated. Additionally, the restricted IL-1ra expression in secretory phase fallopian tubes and absence in extrauterine pregnancy tube samples might be an important mechanism on the molecular base to prevent ectopic pregnancies within the oviduct which needs further investigation. The finding that IL-

$3951 \mathrm{R}$ tI is expressed in both cycle phases independent of a pregnancy in addition to the embryos own IL-1 $\beta$ expression supports the concept of an early embryo-maternal dialogue facilitating a proper implantation process. 


\section{Acknowledgements}

We thank all women who participated in this study. Also we would like to thank

400 Ursula Löhrmann for her help with preparing the sections for immunohistochemical staining. This work was funded by the German Research Society (Deutsche Forschungsgemeinschaft, DFG) to AP Hess (HE 3544/2-1).

405 


\section{References}

Abbondanzo S.J., Cullinan E.B., McIntyre K., Labow M.A. and Stewart C.L., 1996. Reproduction in mice lacking a functional Type 1 IL-1 receptor. Endocrinology 137, 3598-3601.

410 Brabec, C.M., Hill, J.A., 2000. Cytokines/growth factors in the human fallopian tube. In: Hill J.A. (ed) Cytokines in human reproduction. New York: Wiley, 228.

Chomczynski, P., Sacchi, N., 1987. Single step method of RNA isolation by acid guanidinium thiocyanate-phenol-chloroform extraction. Anal. Biochem. 162, 156-159.

415 Cohen, P.E., Pollard, J.W., 1998. Normal sexual function in male mice lacking a functional type 1 interleukin 1 (IL-1) receptor. Endocrinology 139, 815-818.

Colotta F., Re F., Muzio M., Bertini R., Polentarutti N., Sironi M., Giri J.G., Dower S.K., Sims J.E., Mantovani A., 1993. Interleukin-1 type II receptor: a decoy target for IL-1 that is regulated by IL-4. Science 261, 472-475.

420 De, M., Sanford, T.R., Wood, G.W., 1993. Expression of interleukin 1, interleukin 6 and tumor necrosis factor $\alpha$ in mouse uterus during the pre-implantation period of pregnancy. J. Reprod. Fertil. 97, 83-89.

De los Santos, M.J., Mercader, A., Frances, A., Portoles, E., Remohi, J., Pellicer, A., and Simon, C., 1996. Role of Endometrial Factors in Regulating Secretion of 425 Components of the Immunoreactive Human Embryonic Interleukin-1 System during Embryonic Development. Biol. Reprod. 54, 563-574. 
Dimitriadis, E., White, C.A., Jones, R.L., Salamonsen, L.A., 2005. Cytokines, chemokines and growth factors in endometrium related to implantation. Hum Reprod. Update.11, 613-30.

430 Dinarello, C.A., 1994. The interleukin-1 family: 10 years of discovery. FASEB J 8, $1314-1325$.

Dower, S.K., Kronheim, S.R., Hopp, T.P., Cantrell, M., Deeley, M., Gillis, S., Henney, C.S., Urdal, D.L., 1986. The cell surface receptors for interleukin-1 $\alpha$ and interleukin-1 $\beta$ are identical. Nature 324, 266-268.

435 Fukuda, M., Azuma, C., Kanai, T., Koyama, M., Kimura, T., Saji, F., 1995. Interleukin-1 receptor antagonist expression in epithelial cells of human endometrium. Int. J. Gynaecol. Obstet. 49, 305-310.

Gardner, D.K., Lane, M., Calderon, I., Leeton, J. 1995. Environment of the preimplantation human embryo in vivo: metabolite analysis of oviduct and uterine fluids and metabolism of cumulus cells. Fertil. Steril. 65, 349-353.

Ganaiem, M., Abuelhija, M., Lunenfeld, E., Cherniy, N., Weisze, N., Itach, S.B., Breitbart, H., Apte, R., Huleihel, M., 2009. Effect of interleukin-1 receptor antagonist gene deletion on male mouse fertility. Endocrinology 150, 295303

445 Hannum, C.H., Wilcox, C.J., Arend, W.P., Joslin, F.G., Dripps, D.S., Heimdal, P.L., Armes, L.G., Sommer, A., Eisenberg, S.P., and Thompson, R.C., 1990. Interleukin-1 receptor antagonist activity of a human interleukin-1 inhibitor. Nature 343, 336-340. 
Hess, A.P., Hamilton, A.E., Talbi, S., Dosiou, C., Nyegaard, M., Nayak, N., Genbecev-Krtolica, O., Mavrogianis, P., Ferrer, K., Kruessel, J., Fazleabas, A.T., Fisher, S.J., Giudice, L.C., 2007b. Decidual stromal cell response to paracrine signals from the trophoblast: amplification of immune and angiogenic modulators. Biol. Reprod. 76, 102-117.

Hess, A.P., Nayak, N.R., Giudice, L.C., 2007a. Oviduct and Endometrium: cyclic changes in the primate oviduct and endometrium. In: Neill J.D. (Ed.), The Physiology of Reproduction. Elsevier, St. Louis, pp. 359-403.

Huang, H.Y., Chan, S.H., Wu, C.H., Wang, C.W., Lai, C.H., Soong, Y.K., 2005. Interleukin-1 system messenger ribonucleic acid and protein expression in fallopian tube may be associated with ectopic pregnancy. Fertil. Steril. 84, $1484-1492$.

Huang, H.Y., Wen, Y., Kruessel, J.S., Raga, F., Soong, Y.K., Polan, M.L., 2001. Interleukin (IL)-1beta regulation of IL-1beta and IL-1 receptor antagonist expression in cultured human endometrial stromal cells. J. Clin. Endocrinol. Metab. 86, 1387-1393.

465 Kauma, S., Matt, D., Strom, S., Eierman, D., Tuner, T., 1990. Interleukin-1 $\beta$ (IL-1 $\beta$ ), human leukocyte antigen HLA-DR $\alpha$, and transforming growth factor- $\beta$ (TGF$\beta)$ expression in endometrium, placenta and placental membranes. Am. J. Obstet. 163, 1430-1437.

Krussel, J.S., Bielfeld, P., Polan, M.L., Simon, C., 2003. Regulation of embryonic implantation. Eur. J. Obstet. Gynecol. Reprod. Biol. 22, 110 Suppl, 2-9. 
Krussel, J.S., Simon, C., Rubio, M.C., Pape, A.R., Wen, Y., Huang, H.Y., Bielfeld, P., Polan, M.L., 1998. Expression of interleukin-1 system mRNA in single blastomeres from human preimplantation embryos. Hum. Reprod. 13, 22062211.

March, C.J., Mosley, B., Larsen, A., Cerretti, D.P., Braedt, G., Price, V., Gillis, S., Henney, C.S., Kronheim, S.R., Grabstein, K., et al., 1985. Cloning, sequence and expression of two distinct human interleukin-1 complementary DNAs. Nature 315, 641-647.

Noyes, R.W., Hertig, A.T., Rock, J., 1950. Dating the endometrial biopsy. Fertil. 480 Steril. 1, 3-25.

Popovici, R.M., Betzler, N.K., Krause, M.S., Luo, M., Jauckus, J., Germeyer, A., Bloethner, S., Schlotterer, A., Kumar, R., Strowitzki, T., von Wolff, M., 2006. Gene expression profiling of human endometrial-trophoblast interaction in a coculture model. Endocrinology 147, 5662-5675.

485 Pretto, C.M., Gaide Chevronnay, H.P., Cornet, P.B., Galant, C., Delvaux, D., Courtoy, P.J., Marbaix, E., Henriet, P., 2008. Production of interleukin1alpha by human endometrial stromal cells is triggered during menses and dysfunctional bleeding and is induced in culture by epithelial interleukin1alpha released upon ovarian steroids withdrawal. J. Clin. Endocrinol. Metab. 93, 4126-4134.

Seifer, D.B., Romero, R., Berlinsky, D., Hanning, R.V., 1993. Absence of immunoreactive cytokines in supernatants of individual preimplantation human embryos. Am. J. Reprod. Immunol. 30, 105-107. 
Sheth, K.V., Roca, G.L., Al-Sedairy, S.T., Parhar, R.S., Hamilton, C.J.C.M., AlAbdul Jabbar, F., 1991. Prediction of successful embryo implantatiom by measuring interleukin-1-alpha and immunosuppressive factor(s) in preimplantation embryo cultute fluid. Fertil. Steril. 55, 952-957.

Simon, C., Frances, A., Lee, B.Y., Mercader, A., Huynh, T., Remohi, J., Polan, M.L., Pellicer, A., 1995. Immunohistochemical localization, identification and regulation of the interleukin-1 receptor antagonist in the human endometrium. Hum. Reprod. 10, 2472-2477.

Simon, C., Frances, A., Piquette, G.N., El Danasouri, I., Zurawski, G., Dang, W., Polan, M.L., 1994a. Embryonic implantation in mice is blocked by interleukin-1 receptor antagonist. Endocrinology 134, 521-528.

505 Simon, C., Frances, A., Piquette, G.N., Hendrickson, M., Milki, A., and Polan, M.L., 1994b. Interleukin-1 system in the materno-trophoblast unit in human implantation: Immunohistochemical evidence for autocrine/paracrine function. J Clin. Endocrinol. Metab. 78, 847-854.

Simon, C., Piquette, G.N., Frances, A., Polan, M.L., 1993a. Localization of 510 interleukin-1 receptor type I and interleukin-1 beta in human endometrium throughout the menstrual cycle. J. Clin. Endocrinol. Metab. 77, 549-555.

Simon, C., Piquette, G.N., Frances, A., Westphal, L.M., Heinrichs, W.L., and Polan, M.L., 1993b. Interleukin-1 type I receptor messenger ribonucleic acid expression in human endometrium throughout the menstrual cycle. Fertil. Steril. $59,791-796$. 
Sims, J.E., Gayle, M.A., Slack, J.I., Alderson, M.R., Bird, T.A., Giri, J.G., Colotta, F., Re, F., Mantovani, A., Shanebeck, K., et al., 1993. Interleukin-1 signaling occurs exclusively via the type I receptor. Proc. Natl. Acad. Sci. 90, 6155-6159.

Strakova Z., Mayrogianis P., Meng X., Hastings J.M., Jackson K.S., Cameo P., Brudney A., Knight O., and Fazleabas AT, 2005. In Vivo Infusion of Interleukin-1 $\beta$ and Chorionic Gonadotropin Induces Endometrial Changes that Mimic Early Pregnancy Events in the Baboon. Endocrinology 149, 4097-4104

Tackacs, L., Kavacs, E.J., Smith, M.R., Young, H.A., Durum, S.K., 1988. Detection of IL- $1 \alpha$ and IL-1 $1 \beta$ gene expression by in situ hybridization. Tissue localization of IL-1 mRNA in the normal C57BL/6 mouse. J. Immunol. 141, 3081-3094. 


\section{Figure Legends}

\section{Figure 1}

530 Fig. 1 Representative RT-PCR-gelelectrophoresis for IL-1ß (549 bp), IL-1ra (424 bp) and IL-1R t1 (284 bp) for 3 samples each showing that the gene expression of IL-1 $\beta$, Il-1ra and Il-1R t1 within the length of the fallopian tube has no spatial difference ( $\beta$ actin with 838 bp serves as control). All oviduct samples were divided into fimbrial, ampullary and isthmic parts and investigated separately by RT-PCR. From the total of

53519 samples, all were positive for $\beta$-actin mRNA expression (M - DNA size marker, $\mathrm{p}$ - proliferative, s - secretory, f - fimbrial, a - ampullary, i - isthmic).

\section{Figure 2}

Fig. 2 Representative RT-PCR gelelectrophoresis for temporal expression patterns of

540 IL-1 $\beta$, IL-1ra and IL-1R tI showing a temporal and therefore most likely hormonal regulation of IL-1 $\beta$ and IL-1ra, whereas the receptor was expressed in all samples. From the total of 23 samples, all were positive for $\beta$-actin mRNA expression (M DNA size marker, $\mathrm{p}$ - proliferative, $\mathrm{s}$ - secretory, $\mathrm{m}$ - menopausal, iup - intrauterine pregnancy, eup - extrauterine pregnancy).

\section{Figure 3.}

Fig. 3 Immunohistochemistry staining of representative samples from fallopian tubes of the secretory (A-H) and proliferative phase (I-P) (panel A-G and I-O 200× magnification, panel B-H and J-P 400× magnification). Panels A and B represent the negative control of secretory phase oviducts, panel I and J represent the negative 
control (no first antibody) of proliferative phase oviducts. Note that IL-1 $\beta$ is strong expressed in the luminal epithelium and also in the small vessel endothelium of secretory phase oviducts $(\mathrm{C}, \mathrm{D})$, whereas the staining for IL-1 $\beta$ in the luminal epithelium of proliferative phase oviducts was less intense and only a weak staining was localized in the small vessel endothelium ( $3 \mathrm{~K}, \mathrm{~L})$. IL-1R t1 is expressed in the luminal epithelium, small vessel endothelium and glandular epithelium of secretory phase samples (E, F). In comparison, the proliferative sample showed only a sporadic staining for the IL-1R t1 in the luminal epithelium and no staining either in the vessel endothelium or in the glandular epithelium (M, N). G and $\mathrm{H}$ show an intense staining 560 of IL-1 ra in the luminal epithelium and the small vessel endothelium of secretory phase oviducts whereas a staining for IL-1 ra in proliferative oviducts was completely absent. 
Table 1

\begin{tabular}{|c|c|c|c|c|}
\hline mRNA & $\begin{array}{c}\text { size of } \\
\text { amplified } \\
\text { fragment }[\mathrm{bp}]\end{array}$ & $\begin{array}{l}\text { position of } \\
\text { primers on } \\
\text { cDNA }\end{array}$ & $3 / 5^{\prime}$ - end & sequence of oligonucleotide $\left(5^{\prime} \rightarrow 3^{\prime}\right)$ \\
\hline \multirow[t]{2}{*}{$\beta$-actin } & 838 & $294-325$ & 5 '-end & ATC TGG CAC CAC ACC TTC TAC AAT GAG CTG CG \\
\hline & & $1100-1131$ & 3 '-end & CGT CAT ACT CCT GCT TGC TGA TCC ACA TCT GC \\
\hline \multirow[t]{2}{*}{ IL-1 $\beta$} & 549 & $101-122$ & 5 '-end & CAG TGA AAT GAT GGC TTA TTA G \\
\hline & & $628-648$ & $3^{\prime}$-end & CTT TCA ACA CGC AGG ACA GGT \\
\hline \multirow[t]{2}{*}{ IL-1ra } & 424 & $91-114$ & $5^{\prime}$-end & CAG AAG ACC TCC TGT CCT ATG AGG \\
\hline & & $498-514$ & $3^{\prime}$-end & GCTT GTG CAG AGG AAC CA \\
\hline \multirow[t]{2}{*}{ IL-1R tI } & 284 & $341-361$ & 5 '-end & AAG GTG GAG GAT TCA GGA CAT \\
\hline & & $604-624$ & 3 '-end & AGC CTA TCT TTG ACT CCA CTA \\
\hline
\end{tabular}

Tab. 1: primers for synthesis of cDNA clones of human $\beta$-actin, IL-1 $\beta$, Il-1ra and IL-

$1 \mathrm{R}$ tI 
Figure 1

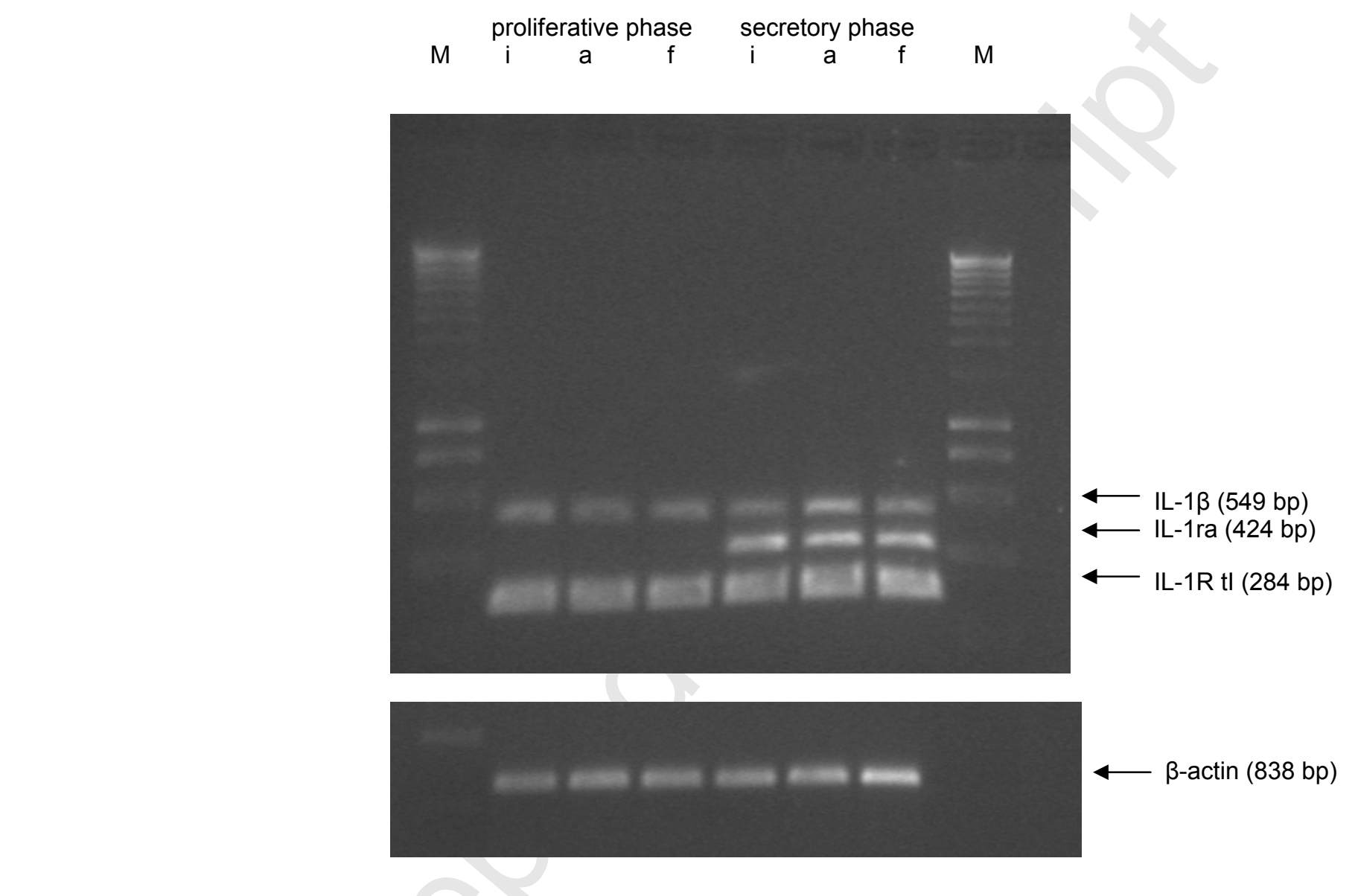

\section{Figures \\ Figures}

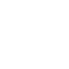

$x^{2}$

$x^{2}$

$x^{2}$

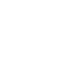

$\sqrt{2}$

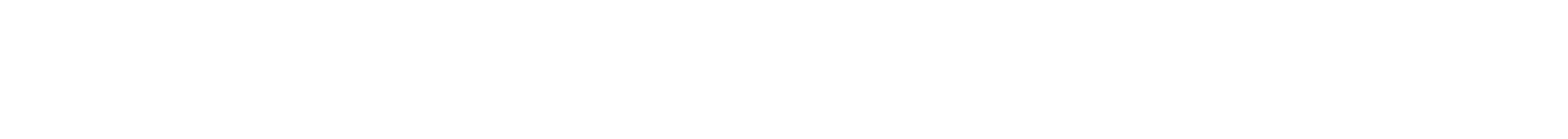

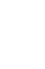


Figure 2

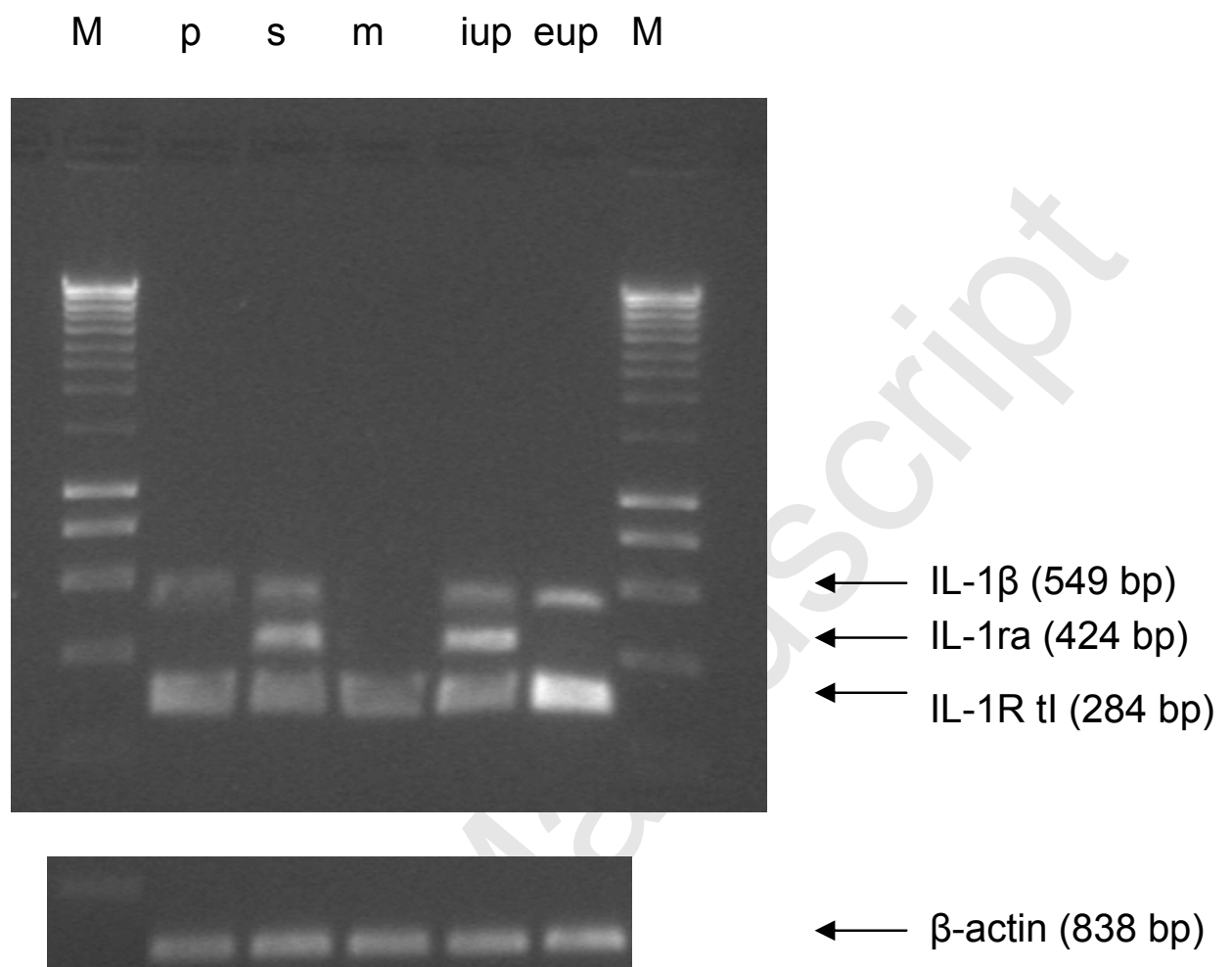


Figure 3

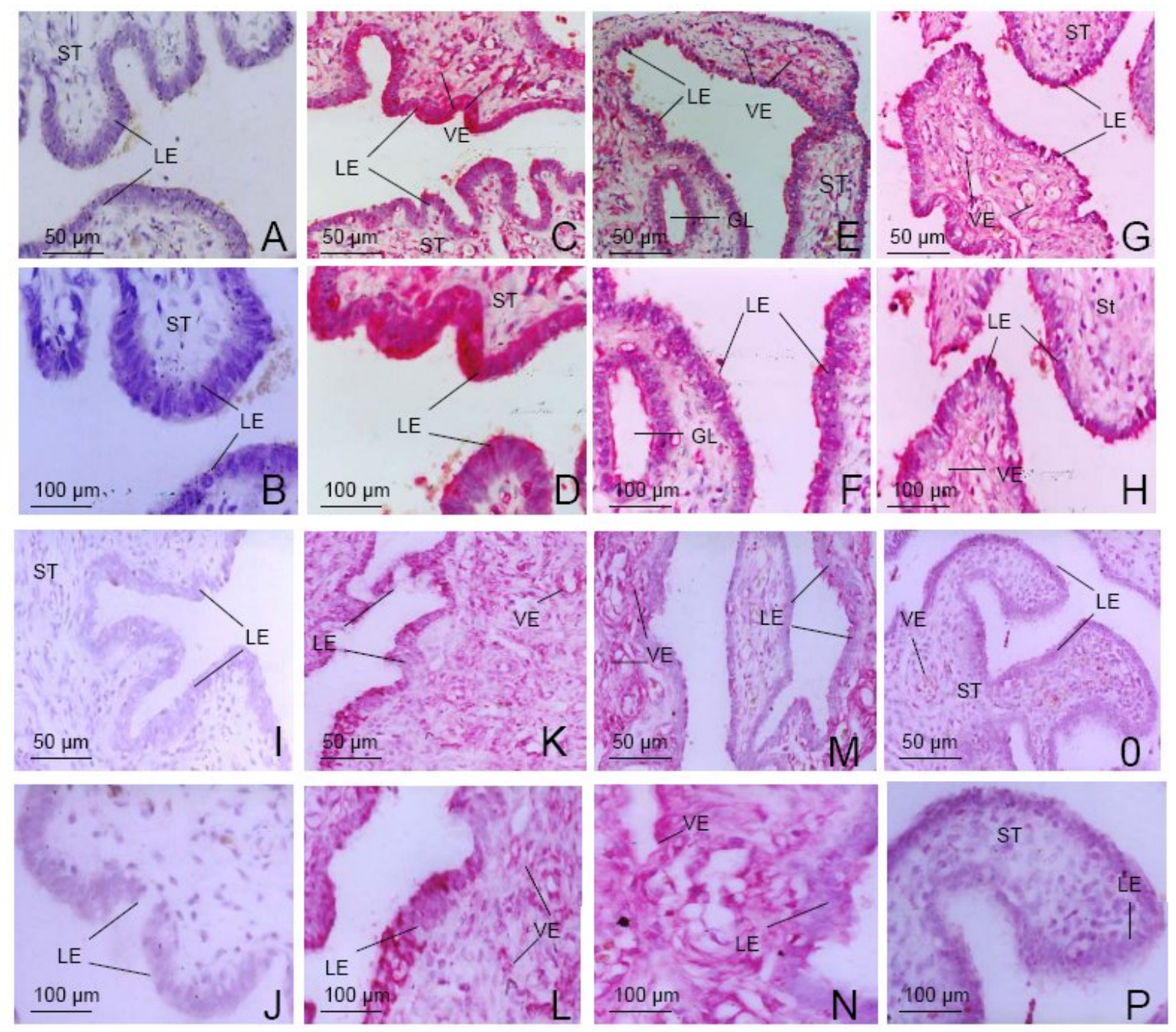

